NASA Technical Memorandum 100108

\title{
Space Station Propulsion System Technology
}

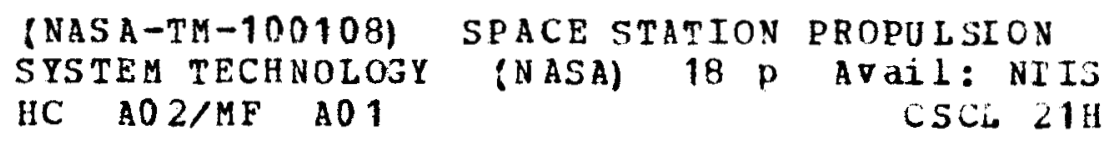

Robert E. Jones, Phillip R. Meng, Steven J. Schneider, James S. Sovey, and Robert R. Tacina

Lewis Research Center

Cleveland, Ohio

Prepared for the

38th International Astronautical Federation Congress

Brighten, United Kingdom, October 10-17, 1987

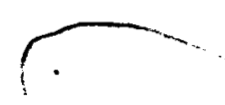


SPACE STATION PROPULSION SYSTEM TECHNOLOGY

Robert E. Jones, Phil11p R. Meng, Steven J. Schnetder, James S. Sovey, and Robert R. Tacina National Aeronautics and Space Administration

Lewis Research Center

Cleveland, Ohto 44135 U.S.A

\section{ABSTRACT}

Two propuision systems have been selected for the space station: $0 / H$ rockets for high thrust applications and the multipropellant resistojets for low thrust needs. These thruster systems integrate very well with the fluid systems on the station. Both thrusters will utilize waste fluids as their source of propellant. The $0 / H$ rocket will be fueled by electrolyzed water and the resistojets will use stored waste gases from the environmental control system and the various laboratories. This paper presents the results of experimental efforts with $0 / H$ and resistojet thrusters to determine their performance and life capability.

\section{INTRODUCTION}

The purpose of this paper is to present the results that have been obtained with propulston system concepts that have been selected for use on the space station. Gaseous fueled $0 / H$ rockets, which use electrolyzed water, have been selected for the high-thrust propulsion system and multiprapellant resistojets which use waste fluids, for the low-thrust system.

Previous papers have discussed the content of the Advanced Development Program and its purposes in considerable deta $11,1,2$ The thruster programs investigated a high-thrust and a lowthrust propulsion system for the inftial operating capability (IOC) space station. The choice of two propulsion systems with differing thrust and operational capabilities provides the space station with a wide variety of propulsion options. The propulsion systems selected for study were 25 to $50 \mathrm{lbf}$ gaseous oxygen-hydrogen fueled rockets and the 0.1 lbf multipropellant resistojets. The combination of these two systems provides the space station with more possible ways of "flying" than are possible with a single thrust level system. The advantages of the dual-mode propulsion system are obvious ones. While sufficlent force is avallable for all large motions of the space station, including contingencies for collision avoldance, delicate maneuvers are continuously possible at a thrust level that will not interfere with scientific research and observations.

An additional benefit of these choices for space station propulsion is the synergism obtained by the integration of the propulsion system with other space station systems. Prope1lants are obtained as by-products from the life support system and the waste gases from the scientific and materials laboratories. Utilization of these fluids alleviates two fundamental problems; resupply of propellants is minimized and the quantity of waste fluids that must be returned to Earth is lessened. The first results in a direct cost saving by reducing the mass to be carried into orbit. The second helps to solve a serlous problem of storing and carrying down wastes and thus improves the shuttle's payload capability in returning to Earth.

This paper presents information on the potential avallability of wastes for use as propellants and results obtained from experimental tests of $0 / H$ thrusters and multipropellant reststojets.

\section{PROPULSION REQUIREMENTS}

The space station propulsion system must be able to provide thrust for altitude maintenance, collision avoidance, attitude control, and momentum management. As studies have continued during Phase $B$, the propulsion requirements have gradualiy increased. Initial requirements and cholce of operating mode and altitude have all been rethought during this study phase. Initialiy, an altitude of $250 \mathrm{nmi}$ was assumed for the station and altitude reboost would be conducted after each shuttle docking. Presentiy, the operating mode proposed for the station is at a lower a)titude and in a mode corresponding to an average acceleration of 0.3 micro-g's. As the atmospheric density vartes over an 11 -year cycle, the altitude required will also vary.

Table 1 compares the total-impulse requirements for a growing and evolving space station over an 17 -year cycle for the initial $250 \mathrm{nmi}$ altitude with the present lower operating altitude and micro-g requirement. These values have been computed by assuming a 1995 IOC station of 500000 ib mass that grows to 1000000 ib in 10-years. The values computed also assume a nominal atmosphere. Note that the altitude has been lowered by up to $70 \mathrm{nmi}$ which eases the problems of the shuttle getting to the station. Most significant, however, is the six-fold increase in propulsion requirements. The space station has never been considered a mission where specific impulse of the propulsion system was paramount. However, as can be seen by the increased levels 
of total-impulse, propulsion system specific impulse is becoming more important and improved levels of spectflc impulse will be sought.

\section{PROPELLANT SOURCE}

To augment the thruster research efforts, several studies were conducted that investigated the propellant source and resupply and their impact on thruster system design.3-5 Initially, those studies assumed that the hydrogen and oxygen would be supplied from supercritical storage tanks simflar to the propellant reactant and supply assembly (PRSA) tanks utflized on the shuttle. As the studies progressed, alternative sources of propellant appeared more attractive. It became apparent from studies of the environmental control and life support systems (ECLSS) that the station could have a significant water disposal problem. These studies clearly identified the potential of electrolyzing this water to provide the required oxygen and hydrogen and the cancomitant savings possible by minimizing resupply. Additional sources of water were also found. Significant quantities of waste and fuel cell water are to be found on board the shuttle and might be transferred to the station. The actual avallabllity of water depends on whether the Bosch or Sabatier concept is selected for the environment control system and the extent of water stored and withdrawn from the shuttle. Table 2 shows the yearly levels of water avallable for each environmental system and assumes shuttle visits at 45 or 90-day intervals and that shuttle water is transferred to the station.

Water, however, is not the only potential propellant source. The selection of the multipropellant resistojet adds significantly to the overall propulsion capability of the station. Continuing studies indicate that there are large quantities of waste gases that could be made avallable for propulsion. 6 If these gases are not utilized for propulsion, then they must be stored and disposed of by a suitable means. That means that these excess or waste gases would have to be returned to Earth or vented, nonpropulsively, in a manner that would not contaminate the station or interfere with observations or experiments. Sources of waste gases identified to date include the shuttle scavenging. ECLSS, MTL, the Japanese and Columbus module laboratories, and attached payloads.

The Materials Technology Laboratory (MTL), with up to 14 experimental facilities operational at the $I O C$, and the international modules will produce varying amounts of excess fluids. Amounts of waste fluids generated by these modules are dependent on the complement of experiments being performed and on the amount of space station crew time spent performing the experiments. Contaminants and associated concentration levels contained in the produced flulds are unavallable at this time. It is assumed that the waste fluids will be cleaned sufficiently to allow for safe, long-term storage and also for use in the resistojet propulsion system.

Attached payload waste gases result from both purging of the experiments and cryogenic bolloff. To avold venting, and its assoclated external contamination impacts, these gases must be collected and stored. These relatively clean gases may then be used to meet other station requirements (e.g.. MTL or propulsion) or be recycled for reuse by the attached payloads where feasible. Attached payload waste gases vary greatiy as a function of $t$ ime in their types and amounts due to relatively short run times at the station (typically 1 to 4 year). An attached payload complement scheduled for operation at or near IOC which require and generate gases is: the Cosmic Ray Nuclef Experiment, the Solar Terrestrial Observatory, the Long Term Cryogentc Storage, and the Active Optic Technology.

Table 3 summarizes the overall space station waste gas inventory for $10 \mathrm{C}$ and growth. 6 The growth predictions are based on the station growing from one-half million lb at IOC to one million $1 \mathrm{~b}$ after 10 years and 2 crew members added every 2 years from $8 \mathrm{crew}$ members at IOC to 18 at IOC +10 years Japanese and Columbus Labs waste gas output is assumed constant for the 10 year period. Attached payload growth predictions are based on station mass growth starting with the above four waste fluld-generating payloads. The amounts of excess water (if any) are not included since many options that affect the water balance have not been defined, e.g., the ECLSS process or water avallable from shuttle scavenging.

The selection of the lower operating altitude as shown in Table 1 has raised the propulsion requirements significantiy and it is not ciear whether waste fluids would be avallable in sufficient quantity to fulfill the entire propulsion requirements. An estimate of the propeliant avallability is obtained by summing the amounts of water from Table 2 with waste gases from Table 3. With a "worst-case" scenario, about one-half of the required propellant would be available. The difference, presumably water, would have to be transported to the station. A "best case" situation would specify the use of the Bosch ECLSS and shuttle visits every 45 days. In this case, potential propellants, water and waste gases, are avallable in excess and the propulsion requirements of Table 1 can be met for each year. Studies of waste water and gas ut111zation as propellants will continue as the space station evolves. However, the economies inherent by the utllization of wastes will not be diminished, even if these propellants are not avallable in sufficient quantity to meet all the propulsion needs in a given year.

\section{HIGH THRUST PROPULSION}

The high thrust propulsion system was selected to be gaseous oxygen-hydrogen fueled rockets. The presumed thrust level was chosen to lie within the 25 to 50 lbf range. 7 while no absolute thrust size could be predetermined, this size seemed the correct one to identify any technology 1ssues. The program initially speciffed that the $0 / F$ mixture should be $4: 1$ to provide maximum 
values of specific impulse. Later, the potential use of propellants from water required that tests be conducted at a mixture ratio of $8: 1$. The program goal was primarily life oriented. Specific impulse would be sacrificed to achieve long operational life. The test program emphasized all $11 \mathrm{fe}$ related aspects of thruster design.

Three small rockets, provided by three different manufacturers were included in this program. Aerojet Techsystems provided a 25-1b thruster and Bell Aerospace provided a 50-1bf thruster; both under contract to NASA Lewis. Rocketdyne provided a 25-1bf thruster, constructed as part of their IRAD program, to Marshall Space Flight Center where the performance and iffe tests were conducted. 8 The results of these test efforts have been extensively reported elsewhere.8-11 Table 4 compares the basic design parameters of the Aerojet, Bel1, and Rocketdyne thrusters. Note that the anticipated level of specific impulse was greater than 400 sec for all thrusters. This estimate was based on anticipated operation at a mixture ratio of $4: 1$. The Rocketdyne thruster was regeneratively cooled and used only 7 to 10 percent of the fuel for film cooling. The Aerojet thruster was also regeneratively cooled but also used extensive fuel film cooling within the chamber. The extent of this cooling was varied from 59 to 95 percent of the fuel flow rate during the experimental program. The Bell thruster, at 50-1bf, was the largest of the three in the program. This high value of thrust was the upper level deemed acceptable for the determination of technology problems. This thruster is regeneratively cooled at the throat and the fuel then enters the chamber as a film. Approximately 6 percent of the fuel is used to $f 19 \mathrm{~m}-\mathrm{cool}$ the nozzle extension. During the initial thruster check-out tests, only minor thruster hardware changes were made, and those were done to improve heat transfer and reduce chamber wall temperatures.

Figure 1 shows the Aerojet thruster mounted on a thrust stand. Figures 2 and 3 are photographs the Bell and Rocketdyne thrusters, respectively. These thrusters all operate at modestly low chamber pressure and have similar overall dimensions. They do, however, differ markedly in the design approach taken, method of fuel injection, nozzle area ratio, and extent of regenerative cooling employed.

During the inftial phases of the investigation, the three thrusters were operated over a range of mixture ratios from 3 to 5 . At this time some minor changes were incorporated in each design. A series of tests, design changes, and retests were done on the Bell thruster to improve the mixing of fuel and oxygen in the combustion chamber. Initial tests gave wall temperatures too high for stainless steel and a nonuniform distribution as well. Adjustments to the oxygen injector cup resulted in uniform and lower wall temperatures. The injector design was changed on the Rocketdyne thruster from the inftial doublet design to a co-axial injection system. In addition, the head plate was changed from stainless steel poraloy material to a solid copper disk with a few injection points for hydrogen to film cool the walls. This change resuited in improved cooling of the headplate and higher thruster performance. The Aerojet thruster underwent no hardware changes and the early tests were used to establish the proper level of $\mathrm{f} 11 \mathrm{~m}$ cooling to insure thruster ilfe.

When the decision was made to test these thrusters at a mixture ratio of $8: 1$, it was clear that some further thruster design modifications were in order. Time did not permit a redesign of each thruster, so compromises were made. For example, the Aerojet thruster, with regenerative cooling of the 100 to 1 area ratio nozzle, should have been redesigned to a smaller area ratio. As this was not possible, the effect was simulated by cooling the hydrogen to a level such that the chamber fuel injection temperature would be that value estimated for less regenerative cooling. In a simflar manner, the Bell thruster material was changed to Hastelloy $X$ from 347 stainless steel and the hydrogen cooling flow was held constant. This resulted in a higher thrust of about 85 ib and a higher chamber pressure at a mixture ratio of $8: 1$. The Rocketdyne thruster had the regenerative cooling flow rerouted, utllizing parallel-flow cooling instead of counter-flow cooling. At no time were any operational difficulties encountered and the test programs proceeded as planned. Table 5 lists the total number of seconds of testing for each thruster at mixture ratios from $2: 1$ to $8: 1$. Note that large times were obtained at mixture ratios of 7 and 8 to 1 . Table 5 also shows the total impulse demonstrated by each thruster over the same range of mixture ratios. The life goa $12 \times 10^{6} 1 \mathrm{~b}$-force-seconds was achieved by the Rocketdyne thruster. Time and funding 1 imited the test programs with Aerojet and Bell but large values of total-impulse were obtalned at high mixture ratios.

These results clearly 11 lustrate that the program goal for life was obtainable. Indeed, an examination of the physical state of the thrusters leads one to conclude that the actual obtainable life is substantially greater. The life of such thrusters should be determined to establish a life and rellability data base and to determine the fallure modes that lead to $11 \mathrm{fe} 11 \mathrm{im} 1 \mathrm{tation}$. future tests are planned to address these issues, as well as to strive for increased levels of specific impulse. It is also important to recognize that these life results were obtained with three different design concepts, provided by three separate contractors, and in no case was any if e-limiting problem uncovered.

Figure 4 compares the specific impulse performance obtained with the Aerojet and Bell thrusters over the mixture ratio range from $2: 1$ to $8: 1$. Both thrusters suffered significant decreases in specific impulse as mixture ratio increased. The data obtained with the Bell thruster were taken with a fixed configuration and a fixed hydrogen flow rate in order to assure adequate cooling of the throat. Thus, chamber pressure and thrust level were increasing as mixture ratio increased from $4: 1$. The Aerojet data were obtained with varying splits of hydrogen used for film cooling; up to 92 percent being used for $f 11 \mathrm{~m}$ cooling at a mixture ratio of $8: 1$. 
These losses in performance for both designs were greater than anticipated and reflect nonoptimized designs. Performance improvements can be obtained by redesigning these thrusters and recognizing that operation will be required over a wide range of mixture ratios, but with primary operation near a mixture ratio of $8: 1$. The impact of such design changes on total life of the thrusters will have to be determined.

\section{LOW THRUST PROPULSION SYSTEM}

The appitication of the resistojet as a space station propulston system imposes new operational considerations on the design of such thrusters. Use of resistojets in a wide variety of spacecraft applications is well known and documented.12,13 Resistojets for these applications are characterized as having a requirement for maximum specific impulse, an operating lifetime of only a few hundred hours, and use with a single propellant. As indicated, previously, the primary criteria for space station resistojets are very long ilfe and operation with a wide variety of potential propellants. $1-3$

Materfal-propellant compatibility had to be addressed in order to select a resistojet material that could provide the useful life required with the wide varlety of possible propellants from ECLSS, MTL, attached payloads or other sources. In these studies two forms of grainstabilized platinum were used. Platinum had been a prevtous cholce for a biowaste resistojet considered in the 1970's because of it's excellent resistance to corrosion and oxidation. Resistance to grain growth, a time at high temperature phenomenon, was required to minimize the likelihood of stress-rupture. The program studied both yttria and zirconia grain-stabilized platinum materials.

Figure 5 shows the test chamber used to evaluate the platinum alloy heaters in contact with potentlal propellants. These tests were conducted with $\mathrm{H}_{2}, \mathrm{CH}_{4}, \mathrm{CO}_{2}, \mathrm{NH}_{3}, \mathrm{~N}_{2}$ and steam in a flowing gas environment at a pressure of about 1.4 atmospheres. All tests except those containing $\mathrm{CH}_{4}$, either alone or in mixtures, were conducted at a heater temperature of 1300 to $1400{ }^{\circ} \mathrm{C}$. Gases containing $\mathrm{CH}_{4}$ were tested at a temperature of $500{ }^{\circ} \mathrm{C}$ to avold thermal decomposition of $\mathrm{CH}_{4}$. These tests were conducted for as long as $2000 \mathrm{hr}$ and have been reported in detai1.14,15 Test results are sumarized in Table 6 and indicate that from a material, or mass lass, standpoint, a $10000 \mathrm{hr}$ operational life should be easily obtained with all propellant-material combinations studied. Figure 6 shows a photo micrograph cross section of the heater tube both before, and after a $2000-\mathrm{hr}$ test at $1300^{\circ} \mathrm{C}$ with $\mathrm{CO}_{2}$. No significant grain growth has occurred and surface attack by $\mathrm{CO}_{2}$ has been minimal. Surface attack was significant with ammonia at $1400^{\circ} \mathrm{C}$, and though no mass loss was observed, a life of $10000 \mathrm{hr}$ would probably not be obtained. When the heater temperature was reduced to below $1000{ }^{\circ} \mathrm{C}$ surface attack by ammonia virtually disappeared.

These tests have recently been expanded to include hydrazine as a potential resistojet propellant. Tests of up to $1000 \mathrm{hr}$ have been conducted with yttria-stabilized platinum at temperature of 1000 and $1400^{\circ} \mathrm{C}$. Results similar to those obtained with ammonia have been obtained in that surface attack occurred at $1400{ }^{\circ} \mathrm{C}$, but none was evident at temperatures of $1000{ }^{\circ} \mathrm{C}$ or less. 16

These tests served several valuable purposes. The compatibility of the platinum material was confirmed with many potential propellants, useful 11 fetime data were obtained and where material-propellant attack occurred, a useful operational temperature range has been determined. A further evaluation of the reststojet as a structure was obtained by conducting a $2000-\mathrm{hr}$ life test using $\mathrm{CO}_{2}$ as the propellant. The purpose of this test was to determine the impact of cyclic thermal and mechanical stresses on the platinum matertal as well as the welded joints. At the conclusion of the tests the thruster shown in Fig. 7 was sectioned to examine the interior surfaces for attack. As expected, there was no indication of chemical attack on the structure that could lead to 11 fe limtting problem. Grain growth of the platinum was observed. Areas of concern were joints; where electron-beam welding locally destroys the grain stabilization, the heater, and the heat exchanger. The heater was expected to show the greatest grain growth due to the high temperature at which it was operated. Grains were observed that were as large as the heater tube wall thickness, which, in time, could lead to breaking of the heater. The heat exchanger body also showed evidence of grain growth, though to a much lesser degree, because the local temperatures were lower. These grains had grown to only about 10 percent of the wall thickness and would probably not rupture within the normally expected iffe of the resistojet.

The laboratory model resistojet shown in Fig. 7 was operated with a variety of gaseous propellants and the performance values obtained are shown in $\mathrm{Fig} .8$. This figure shows a nearly constant range of thrust for all the propellants tested, reflecting the variation in propellant flow rate and power level. The indicated values of specific impulse vary inversely as the square-root of the propeliant molecular weight. Although these data were obtained at $1400{ }^{\circ} \mathrm{C}$ heater temperature, operation with methane would not be conducted at such an elevated temperature in order to avoid dissociation. A lower heater temperature would be used with propellants that decompose thermally or attack the platinum, 1.e. $\mathrm{CH}_{4}, \mathrm{NH}_{3}$, and $\mathrm{N}_{2} \mathrm{H}_{4}$.

\section{Engineering Model Resistojet Design}

The purpose of the endurance test was to serve as a test bed for material compatibility, hardware fabrication processes, operating conditions, and strategies for ground testing multipropellant resistojets with long iffe characteristics. The information gained from this test 
has yielded valuable insight into the design of the engineering model resistojet, which will serve as a pre-prototype space station thruster. The engineering model resistojet incorporates significant design improvements over the laboratory model thruster, which will give it rellable long-life characteristics. Figure 9 is a photograph of the space station resistojet and figure 10 is a cross-sectional sketch with the major features identified. The resistojet design is the result of a Rocketdyne/Technion effort, on contract to NASA Lewis. The detalled discussion of the design chotces, features and construction detalis can be found in Ref. 17.

Among the most significant differences between the laboratory model and engineering model resistojets are:

(1) The coiled tube heater is replaced by a coiled sheathed heater. This eliminates the potential for shorting of the heater by surrounding the current-carrying resistance element with a layer of compressed magnesia insulation, which is covered with a metal sheath. The sheathed heater is wound around a rugged central heat exchanger and is secured in position by a series of semi-circular grooves machined into the outer surface of the forward half of the heat exchanger. This feature eliminates the possibility of movement of the heater, which would result in changes in the thermal characteristics of the thruster, and provides a large contact area between the heater and heat exchanger. The temperature difference between the heater and heat exchanger in this design is inherently low, and preliminary thermal tests on the first engineering model indicate that its temperature drop is less than $200^{\circ} \mathrm{C}$ for a nominal heater temperature of $1200{ }^{\circ} \mathrm{C}$.

(2) Large-surface-area diffusion bonds replace the stress-bearing EB welds used in the laboratory model thruster. The diffusion bonds are backed by EB welds located in relatively cool reglons of the engineering model thruster to ensure gas-tight integrity. This joining technique eliminates potential fallures due to adverse effects on the grain stabilization of the platinum by the EB welding process.

(3) A thick-walled pressure vessel/heat exchanger replaces the thin-walled pressure vessel employed by the laboratory model thruster. This change improves the stress-rupture characteristics of the engineering model resistojet. However, the question of grain growth within the walls of the engineering model heat exchanger persists, since the thruster heat exchanger is planned to operate at a maximum temperature of 1200 to $7400{ }^{\circ} \mathrm{C}$.

Table 7 presents some preliminary performance data for the engineering model resistojet. These data were obtained for a wide variety of potential propellants. These preliminary tests were conducted with the propellant chamber pressure held constant at 40 psia and the heater current $11 \mathrm{mited}$ to $23 \mathrm{~A}$. Since this was the first resistojet to be tested, the current was kept low so as not to overtemperature the heater while obtaining some basic understanding of how this resistojet operates. For the higher heat capacity gases the power level could have been increased to and well beyond the $500 \mathrm{~W}$ level. However, there were no thermocouples installed on the heater and we did not wish to risk damage on the first model. Subsequently, thermocouples have been added along the heater and a better understanding of the heater temperature, propellant flow rate, and type has been obtained.

As shown in Table 7 , the thrust levels were virtually constant, varying between 64 and $80 \mathrm{~m} \mathrm{1b}$, but the power and specific impulse varied in relation to the propellant molecular weight and heat capacity. Since these data were obtained, more extensive testing has occurred and a 11 fe test with carbon dioxide propellant has begun. 18

\section{CONCLUOING REMARKS}

The experimental efforts discussed in this paper have produced results that clearly indicate that $0 / H$ rockets and the multipropellant resistojets can meet the propulsion requirements of the space station. These propulsion systems will utilize waste water and gases as propeliants. The studies have indicated that the use of wastes as propellants can meet part, if not all, of the space station's propulsion requirements. Further, the use of wastes as propellants resolves the issue of their on-orbit disposal and greatly minimizes the amount of waste material that must be returned to Earth. The experimental efforts have also shown that both thruster types have the iffe capability that is needed for use on the space station. Actual life determination and the identification of life limiting effects still needs to be addressed for all those future applications where thrusters, utilizing any combination of propellants, will be refueled to meet the propulsion demands of long duration spacefilght.

\section{REFERENCES}

1. Richmond, R. J., and Jones, L.W., Space Station Advanced Propulsion and Fluid Management Program. 1985 JANNAF Propulsion Meeting - Vol 1 1985, Pp. 413-421.

2. Jones, Robert E., Space Station Propulsion: The Advanced Development Program at Lewts. AIAA Paper 85-11541 Presented at 21 st AIAA Joint Propulsion Conference, July 8-10, 1985.

3. Donovan, R. M., Sovey, J. S., and Hannum, N.B., Space Station Propulsion Analysis Study. NASA IM 83715, presented at 20th AIAA Joint Propulsion Conference, Paper No. AIAA-84-1326, June 1984.4 
4. Klemetson, R. W., Garrison, P. W., and Hannum, N. B., An Evaluation of Oxygen/Hydrogen Propulsion Systems for the Space Station: AIAA Paper 85-1156, Presented at 21st AIAA Jo1nt Propulsion Conference, July 8-10, 1985.

5. Shoj1, J. M., et al., Oxygen/Hydrogen Space Station Propulsion System Concept Definition for IOC. AIAA Paper 86-1561 presented at 21 st AIAA Joint Propulsion Conference, June, 1986.

6. Tacina, R. R., Conceptual Design and Integration of a Space Station Resistojet Propulsion Assembly. AIAA Paper $87-1860$ presented at 23 rd Joint Propulsion Conference, June 29-July $2,1987$.

7. Woo, H. H., Falangas, E. T, and Finley, J. A.: Preliminary Evaluation of a Reaction Control System for a Space Station. AIAA Paper 86-2152, Presented at AIAA/AAS Astrodynamics Conference, August 18-21, 1986.

8. Heckert, B. J., Allums, S. L., and Carrosquillo, E. A., 25 lbf Gaseous 0xygen-Gaseous Hydrogen Thruster for Space Station. Presented at 1986 JANNAF Propulsion Meeting. August 1986.

9. Robinson, P.J. and Rosenthal, S. E., A Proven 25-lbf $\mathrm{H}_{2} / \mathrm{O}_{2}$ Thruster for Space Station Auxtliary Propulsion AIAA-86-1560, presented at 22nd AIAA Joint Propulsion Conference, June $16-18,1986$.

10. Senneff, J. M. and Richter, G.P., A Long-Life 50 lbf $\mathrm{H}_{2}$ Thruster for Space Station Auxiliary Propulsion. AIAA-86-1404, presented at 22nd AIAA Joint Propulsion Conference, June, 1986

11. Richter, G. Paul and Price, Harold G., Proven, Long-Life Hydrogen/0xygen Thrusters for Space Station Propulsion. NASA TM-88822, presented at 1986 JANNAF Propulsion Meeting, August, 1986.

12. McKevitt, F. X., Design and Development Approach for the Augmented Catalytic Thruster $(A C T)$, AIAA Paper 81-1255, June 1983.

13. Mirtich, Micheal J., Resistojet Propulsion for Large Spacecraft Systems, AIAA Paper 82-1948, presented at the 16th AIAA International Electric Propulsion Conference, November, 1982 .

14. Whalen, Margaret V., Grisnik, Stanley P. and Sovey James S., Compatibility Experiments of Facilities, Materials and Propellants for Electrothermal Thrusters. NASA TM-86956, presented at 1985 JANNAF Propulsion Meeting., Apri1, 1985.

15. Morren, W. Earl, Whalen, Margaret V. and Sovey, James S., Performance for Space Station Auxtliary Propulsion, AIAA Paper 86-1435, presented at 22nd AIAA Joint Propulsion Conference, June, 1986.

16. Personal Communication: Margaret V. Whalen., September, 1986.

17. Pugmire, T. K., Cann, G. L. Heckert, B. and Sovey, J. S., A 10,000 Hour Life Multipropellant Engine for Space Station Application. AIAA Paper 86-1403, presented at 22nd AIAA Joint Propulsion Conference, June, 1986.

18. Morren, W. Earl, Hay, Stuart S., Haag, Thomas W. and Sovey, James S.: Performance Characterization of An Engineering Model Multipropellant Resistojet for Space Station Application. AIAA Paper 87-2120, AIAA 23rd Joint Propulsion Conference, San Diego, California, June 29-July 2, 1987. 
TABLE 1. - TOTAL-IMPULSE REQUIRED FOR REBOOST/ALTITUDE MAINTENANCE

[Nominal atmosphere assumed.]

\begin{tabular}{|l|c|c|c|}
\hline Year & \multicolumn{2}{|c|}{$\begin{array}{c}\text { Variable altitude } \\
\text { a verage, } \\
\text { m.3 }\end{array}$} & $\begin{array}{c}\text { Nominal 250 } \mathrm{nmi} \\
\text { altitude }\end{array}$ \\
\cline { 2 - 5 } & $\begin{array}{c}\text { Altitude, } \\
\text { nmi }\end{array}$ & $\begin{array}{c}\text { Impulse, } \\
\text { lbf-sec }\end{array}$ & $\begin{array}{c}\text { Impuise, } \\
\text { ibf-sec }\end{array}$ \\
\hline 1995 & 189 & 3840854 & 657840 \\
1996 & 184 & 4500470 & 358910 \\
1997 & 180 & 5054046 & 313331 \\
1998 & 180 & 4855411 & 278491 \\
1999 & 180 & 5356076 & 306930 \\
2000 & 192 & 4753118 & 523467 \\
2001 & 202 & 5274946 & 1027970 \\
2002 & 213 & 5967411 & 1905387 \\
2003 & 221 & 6480000 & 2646000 \\
2004 & 210 & 7478224 & 2162223 \\
2005 & 205 & 7621082 & 1718600 \\
\hline Total & & 61181635 & 11899149 \\
\hline
\end{tabular}

TABLE 2. - WATER AVIALABLE FOR PROPULSION $1 \mathrm{bm} / \mathrm{yr}$

\begin{tabular}{|c|c|c|c|c|c|c|c|c|c|c|c|}
\hline Options & 1995 & 1996 & 1997 & 1998 & 1999 & 2000 & 2001 & 2002 & 2003 & 2004 & Total \\
\hline 45 Day vi & $\begin{array}{ll}18 & 140\end{array}$ & 18630 & 18480 & 18970 & 18815 & 19305 & 19155 & 19645 & 19490 & 19980 & 190610 \\
\hline 90 Day visits & 9735 & 10185 & 10030 & 10520 & 10370 & 10860 & 10710 & 11195 & 11045 & 11530 & 106180 \\
\hline $\begin{array}{l}45 \text { Day visits } \\
\text { Sabatier ECLSS }\end{array}$ & 15585 & 15425 & 15280 & 15130 & 14980 & 14830 & 14675 & 525 & 14370 & 14220 & 149020 \\
\hline $\begin{array}{l}90 \text { Day visits } \\
\text { Sabatier ECLSS }\end{array}$ & 7175 & 6985 & 6830 & 6680 & 6530 & 6380 & 6230 & 6075 & 5925 & 5770 & 64580 \\
\hline
\end{tabular}


TABLE 3. - ANNUAL WASTE GAS PRODUCTION FROM ALL SOURCES

[Assumed Bosch ECLSS, changes with Sabatier ECLSS in Parenthesis (1bm/yr).]

\begin{tabular}{|c|c|c|c|c|c|c|c|c|c|c|}
\hline Gas/year & 1995 & 1996 & 1997 & 1998 & 1999 & 2000 & 2001 & 2002 & 2003 & 2004 \\
\hline Argon & 1264 & 1264 & 1264 & 1264 & 1348 & 1348 & 1348 & 1026 & 1026 & 1109 \\
\hline $\mathrm{CO}_{2}$ & 451 & 693 & 451 & 208 & 260 & 260 & 260 & 260 & 260 & 260 \\
\hline $\mathrm{CO}_{2} / \mathrm{CH}_{4}$ & $\begin{array}{c}0 \\
(3740)\end{array}$ & $\begin{array}{c}0 \\
(3740)\end{array}$ & $\begin{array}{c}0 \\
(3740)\end{array}$ & $\begin{array}{c}0 \\
(3740)\end{array}$ & $\begin{array}{c}0 \\
(5610)\end{array}$ & $\begin{array}{c}0 \\
(5610)\end{array}$ & $\begin{array}{c}0 \\
(5610)\end{array}$ & $\begin{array}{c}0 \\
(5610)\end{array}$ & $\begin{array}{c}0 \\
(5670)\end{array}$ & $\begin{array}{c}0 \\
(7480)\end{array}$ \\
\hline Freon & 6 & 6 & 6 & 6 & 8 & 8 & 8 & 8 & 8 & 9 \\
\hline Heltum & 229 & 808 & 896 & 896 & 813 & 813 & 813 & 813 & 41 & 45 \\
\hline Hydrogen & $\begin{array}{l}182 \\
(42)\end{array}$ & $\begin{array}{l}182 \\
(42)\end{array}$ & $\begin{array}{c}322 \\
(182)\end{array}$ & $\begin{array}{c}322 \\
(182)\end{array}$ & $\begin{array}{c}702 \\
(492)\end{array}$ & $\begin{array}{c}394 \\
(184)\end{array}$ & $\begin{array}{l}254 \\
(44)\end{array}$ & $\begin{array}{l}254 \\
(44)\end{array}$ & $\begin{array}{l}254 \\
(44)\end{array}$ & $\begin{array}{l}325 \\
(45)\end{array}$ \\
\hline Nitrogen & 1835 & 1989 & 1835 & 1680 & 2338 & 2338 & 2338 & 2108 & 2108 & 2765 \\
\hline oxygen & 243 & 243 & 243 & 243 & 335 & 335 & 335 & 335 & 335 & 426 \\
\hline Xenon & 88 & 88 & 88 & 88 & 110 & 110 & 110 & 110 & 110 & 132 \\
\hline $\begin{array}{l}\text { Krypton } \\
\text { Totals }\end{array}$ & 80 & 80 & 80 & 80 & 80 & 80 & 80 & 80 & 80 & 80 \\
\hline Bosch & 4378 & 5353 & 5185 & 4787 & 5994 & 5686 & 5546 & 4995 & 4222 & 5203 \\
\hline Sabatier & 7978 & 8953 & 8785 & 8387 & 11394 & 11086 & 10946 & 10394 & 9622 & 12403 \\
\hline
\end{tabular}

TABLE 4. - H/O THRUSTER INITIAL DESIGN PARAMETERS

\begin{tabular}{|l|r|r|r|}
\hline & Rocketdyne & Aerojet & Bel1 \\
\hline Thrust, lbf & 25 & 25 & 50 \\
Specific impulse, sec & 415 & 440 & 410 \\
Nozzle area ratio & 30 & 100 & 40 \\
Chamber pressure, psia & 100 & 75 & 75 \\
Throat diameter, in. & 0.42 & 0.5 & 0.69 \\
Exit diameter, in. & Regen cooled & Regen cooled & Film cooled \\
Type & & 5.0 & 39 \\
\hline
\end{tabular}

TABLE 5. $-\mathrm{O}_{2} / \mathrm{H}_{2}$ THRUSTER TEST SUMMARY

\begin{tabular}{|c|c|c|c|c|c|c|}
\hline \multirow{2}{*}{$\begin{array}{l}\text { Mixture } \\
\text { ratio, } \\
\text { F }\end{array}$} & \multicolumn{2}{|c|}{ Aerojet } & \multicolumn{2}{|c|}{ Bell } & \multicolumn{2}{|c|}{ Rocketdyne } \\
\hline & $\begin{array}{c}\text { Total } \\
\text { duration, } \\
\text { sec }\end{array}$ & $\begin{array}{l}\text { Total } \\
\text { impulse, } \\
\text { lbf-sec }\end{array}$ & $\begin{array}{c}\text { Total } \\
\text { duration, } \\
\text { sec }\end{array}$ & $\begin{array}{l}\text { Total } \\
\text { impulse, } \\
\text { lbf-sec }\end{array}$ & $\begin{array}{c}\text { Total } \\
\text { duration, } \\
\text { sec }\end{array}$ & $\begin{array}{l}\text { Total } \\
\text { impulse, } \\
\text { lbf-sec }\end{array}$ \\
\hline $\begin{array}{l}2 \\
3 \\
4 \\
5 \\
6 \\
7 \\
8\end{array}$ & $\begin{array}{r}60 \\
180 \\
4 \quad 039 \\
224 \\
221 \\
17 \quad 560 \\
118 \\
\end{array}$ & $\begin{array}{rr}1 & 302 \\
5 & 107 \\
89 & 526 \\
5 & 576 \\
4 & 728 \\
428 & 997 \\
3 & 221 \\
\end{array}$ & $\begin{array}{rr}- & 275 \\
1 \quad 619 \\
124 \\
\\
\\
\\
33 \\
65 \\
3116 \\
\end{array}$ & $\begin{array}{rr}-13 & 470 \\
79 & 637 \\
6 & 123 \\
4 & 367 \\
3 & 449 \\
225 & 607 \\
\end{array}$ & $\begin{array}{rr}32 & 148 \\
12 & 697 \\
& 408 \\
& 478 \\
& 440 \\
40 & 237 \\
\end{array}$ & 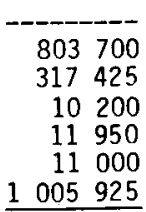 \\
\hline & 22402 & 538457 & 5282 & 332653 & 85968 & 2149200 \\
\hline
\end{tabular}


TABLE 6. - SUMMARY OF GRAIN STABILIZED PLATINUM

EXPERIMENTS

\begin{tabular}{|c|c|c|c|c|}
\hline Propellant & $\begin{array}{c}\text { Coiled } \\
\text { heater } \\
\text { temperature, } \\
\end{array}$ & $\begin{array}{c}\text { Heater } \\
\text { initial } \\
\text { mass, } \\
9\end{array}$ & $\begin{array}{c}\text { Coiled } \\
\text { heater } \\
\text { mass } \\
\text { loss } \\
9^{a}\end{array}$ & $\begin{array}{c}\text { Extrapolated } \\
\text { life, } \\
\text { hr }\end{array}$ \\
\hline \multicolumn{5}{|c|}{ Platinum - Yttria } \\
\hline $\mathrm{CO}_{2}$ & 1400 & 9.0194 & 0.0030 & 300000 \\
\hline $\mathrm{CH}_{4}$ & 500 & 12.6384 & .0008 & 1500000 \\
\hline $\mathrm{H}_{2}$ & 1400 & 12.6589 & .0062 & 200000 \\
\hline $\mathrm{NH}_{3}$ & 1400 & 12.5982 & .0055 & 200000 \\
\hline $\mathrm{H}_{2} \mathrm{O}$ & 1400 & 13.0695 & .0116 & 113000 \\
\hline \multicolumn{5}{|c|}{ Platinum - Zirconia } \\
\hline $\mathrm{CO}_{2}$ & 1400 & 13.1955 & 0.0016 & 800000 \\
\hline $\mathrm{CH}_{4}$ & 500 & 11.6969 & $.0000^{C}$ & 1000000 \\
\hline $\mathrm{H}_{2}$ & 1400 & 13.2093 & .0031 & 400000 \\
\hline $\mathrm{NH}_{3}$ & 1400 & 13.0632 & .0066 & 200000 \\
\hline $\mathrm{H}_{2} \mathrm{O}$ & 1400 & 11.5133 & .0245 & 45000 \\
\hline
\end{tabular}

after $1000 \mathrm{hr}$ operation.

bT ime to 10 percent mass loss.

$\mathrm{c}_{0} 0.0001 \mathrm{~g}$, accuracy of balance.

TABLE 7. - PERFORMANCE OF ENGINEERING MODEL RESISTOJET $[$ Chamber pressure $=40$ psia; Current $=23 \mathrm{~A}$.

\begin{tabular}{|l|r|r|r|r|r|r|r|r|}
\hline Propellant & $\mathrm{H} 2$ & $\mathrm{H}_{\mathrm{e}}$ & $\mathrm{CH}_{4}$ & $\mathrm{AIR}$ & $\mathrm{N}_{2}$ & $\mathrm{Ar}$ & $\mathrm{CO}_{2}$ & $\mathrm{H}_{20}$ \\
\hline $\begin{array}{l}\text { Power, W } \\
\text { Thrust, mlb }\end{array}$ & 251 & 322 & 324 & 432 & 430 & 490 & 405 & 490 \\
$\begin{array}{l}\text { Specific } \\
\text { impulse, sec }\end{array}$ & 318 & 64 & 80 & 74 & 75 & 69 & 77 & 52 \\
\hline
\end{tabular}




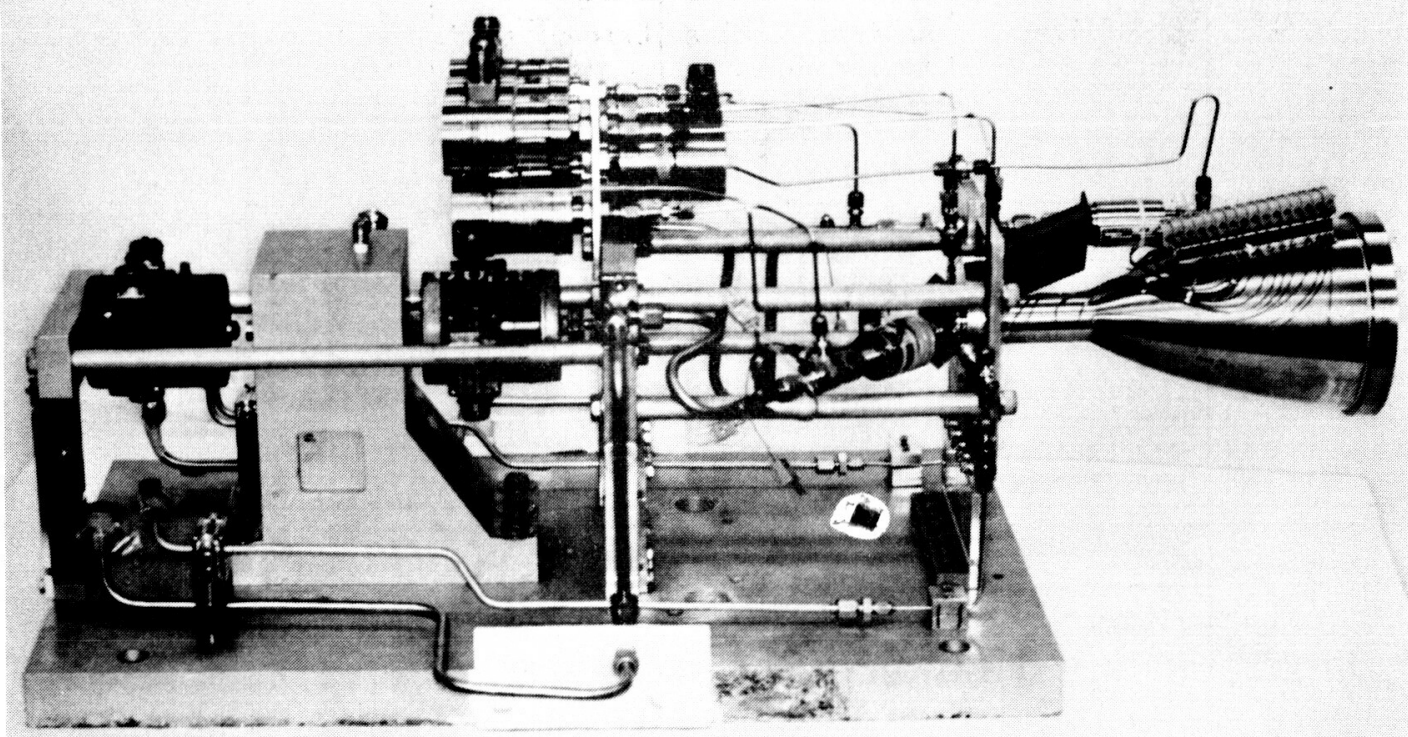

C-86-1827

FIGURE 1. - AEROJET 25-Ibf ROCKET ENGINE ON THRUST STAND.

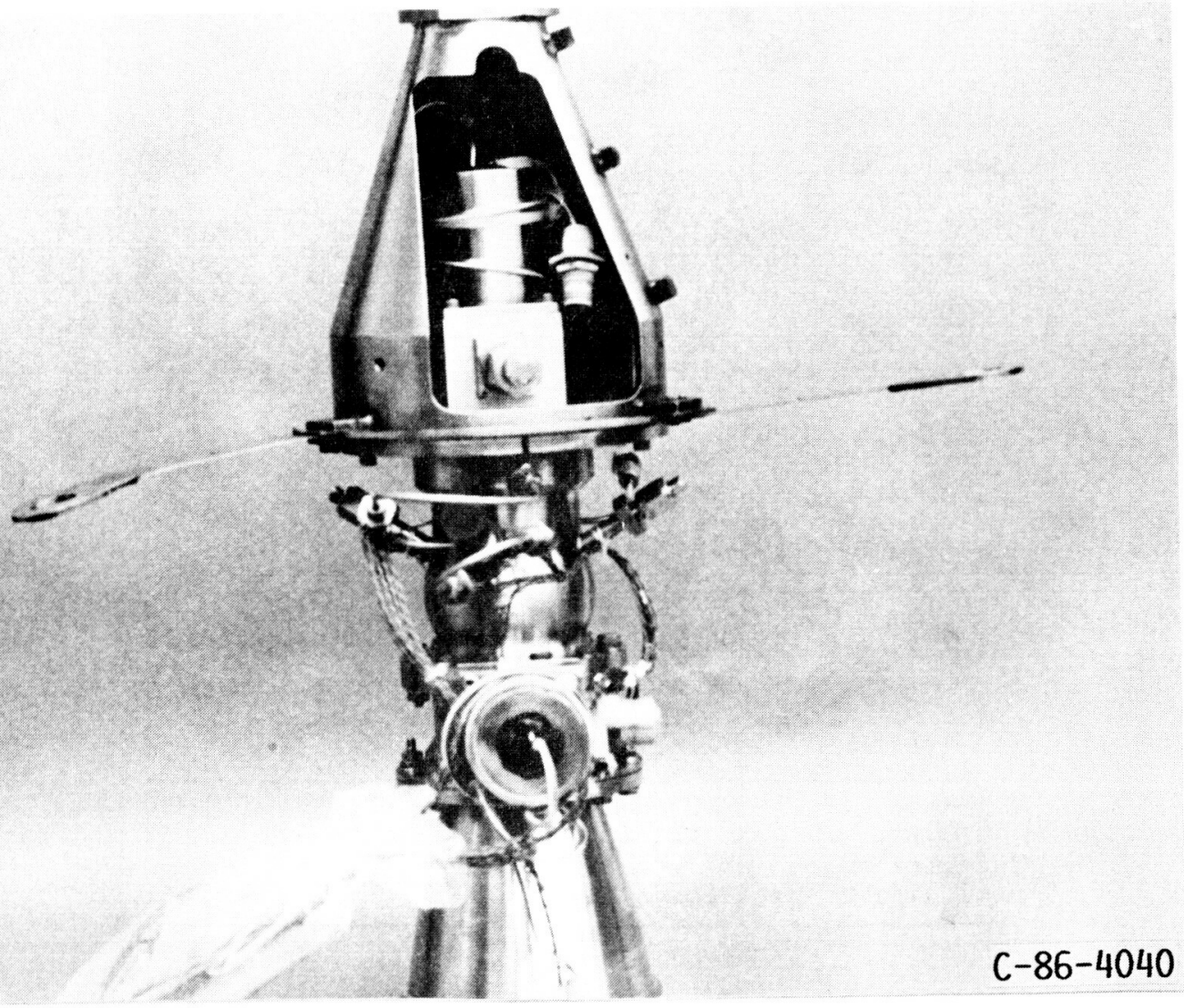

FIGURE 2. - BELL AEROSPACE 50-Ibf THRUST HYDROGEN/OXYGEN ROCKET. 


\section{ORIGINAL PAGE IS
OF POOR QUALTY}

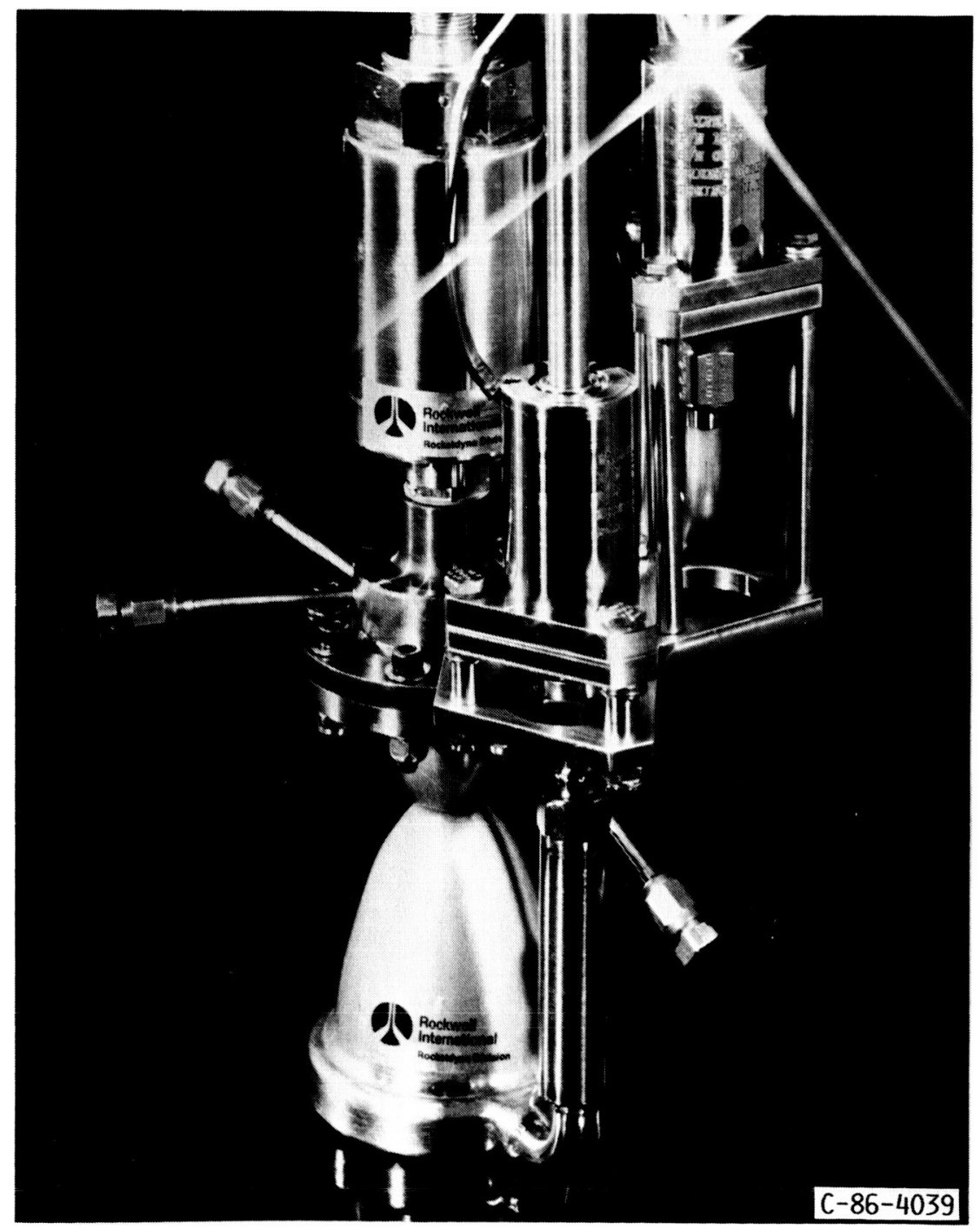

FIGURE 3. -ROCKETDYNE 25-Ibf THRUST HYDROGEN/OXYGEN ROCKET. 


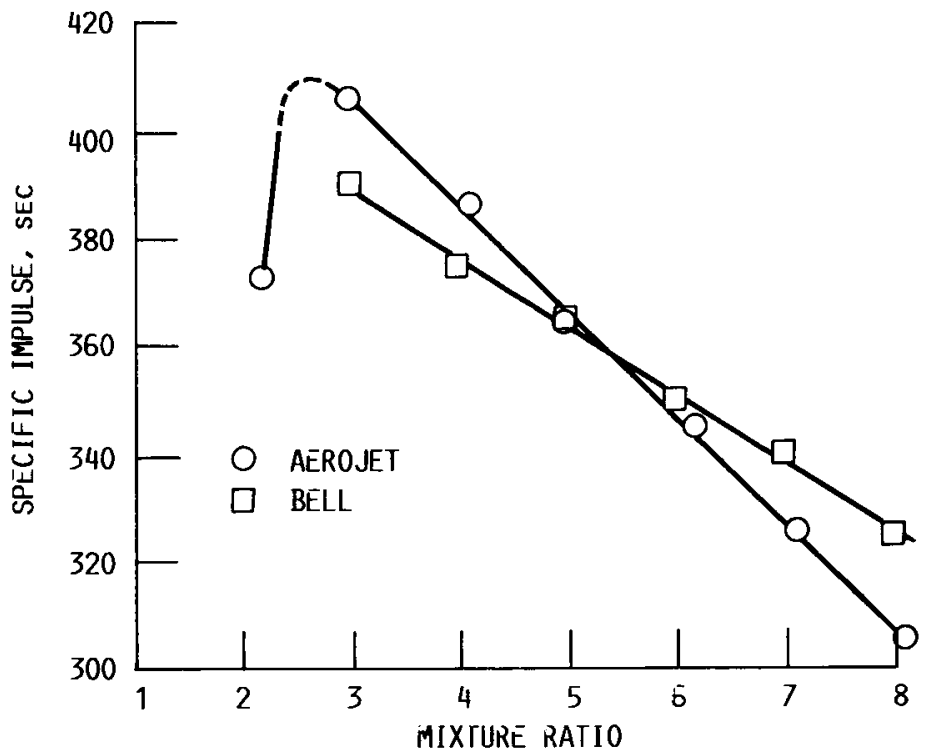

FIGURE 4. - PERFORMANCE OF H/O THRUSTERS OVER A RANGE OF MIXTURE RATIOS. 
ORICTNAL PAGE IS

OF POOR OUGUTY

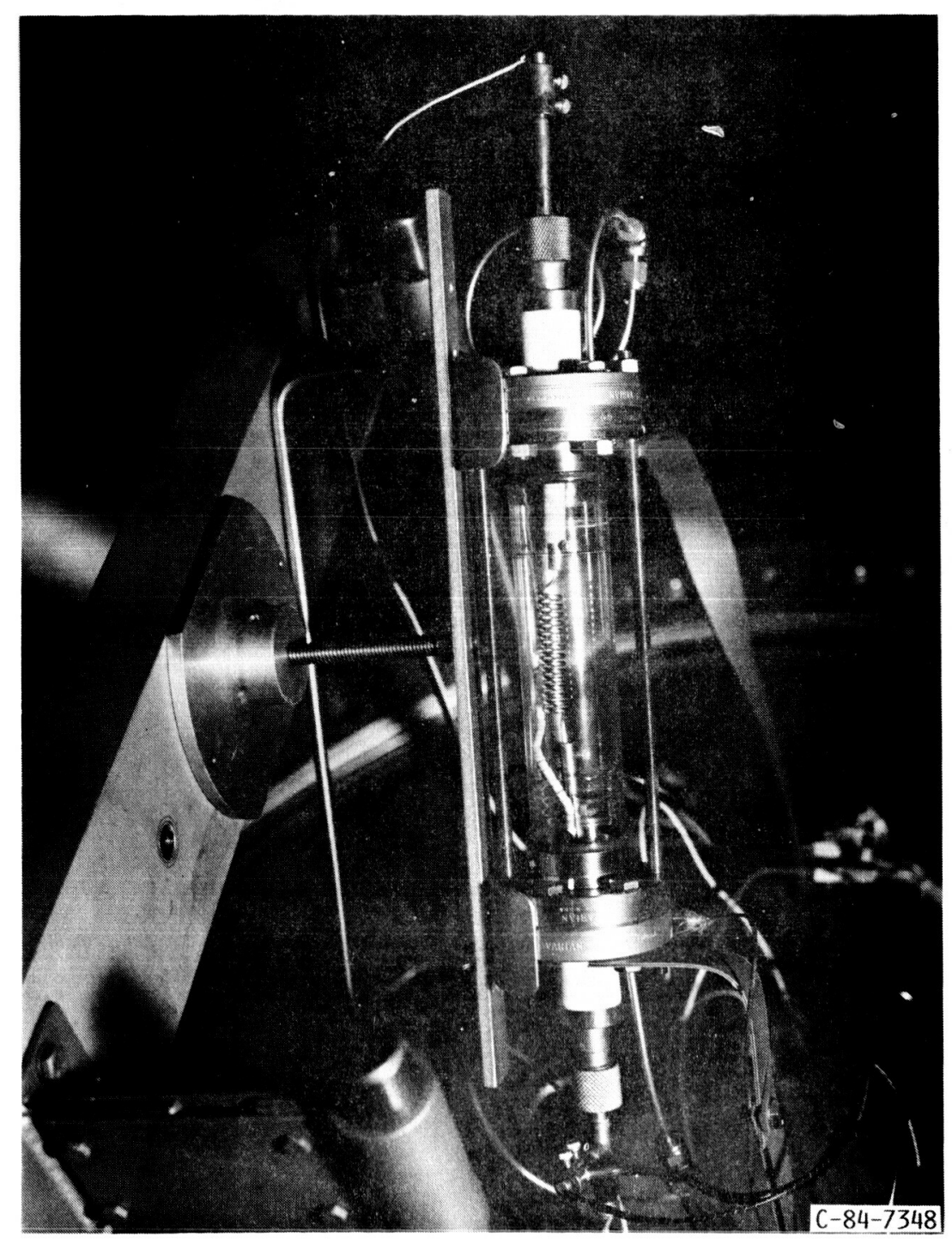

FiguRE 5. - TEST APPARATUS USED TO EVALUATE PROPELLANT-MATERIAL COMPATABILITY FOR LONG-LIFE RESISTOJETS. 


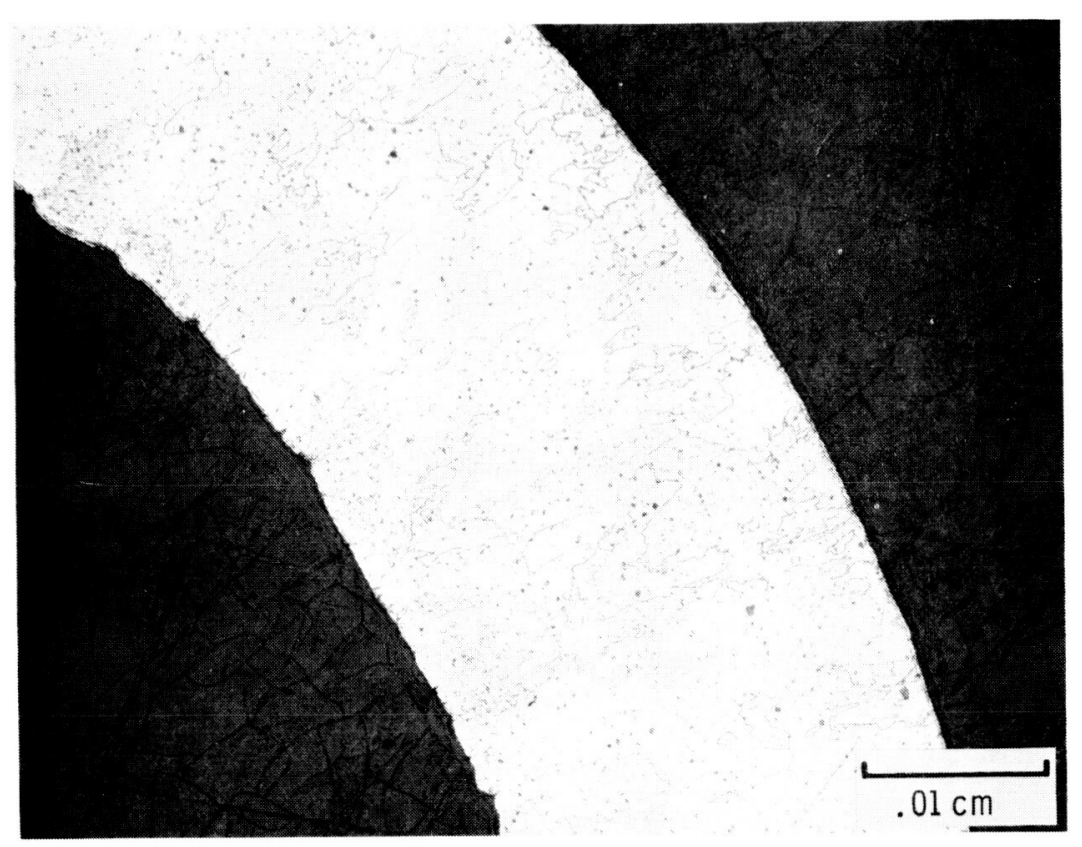

Before

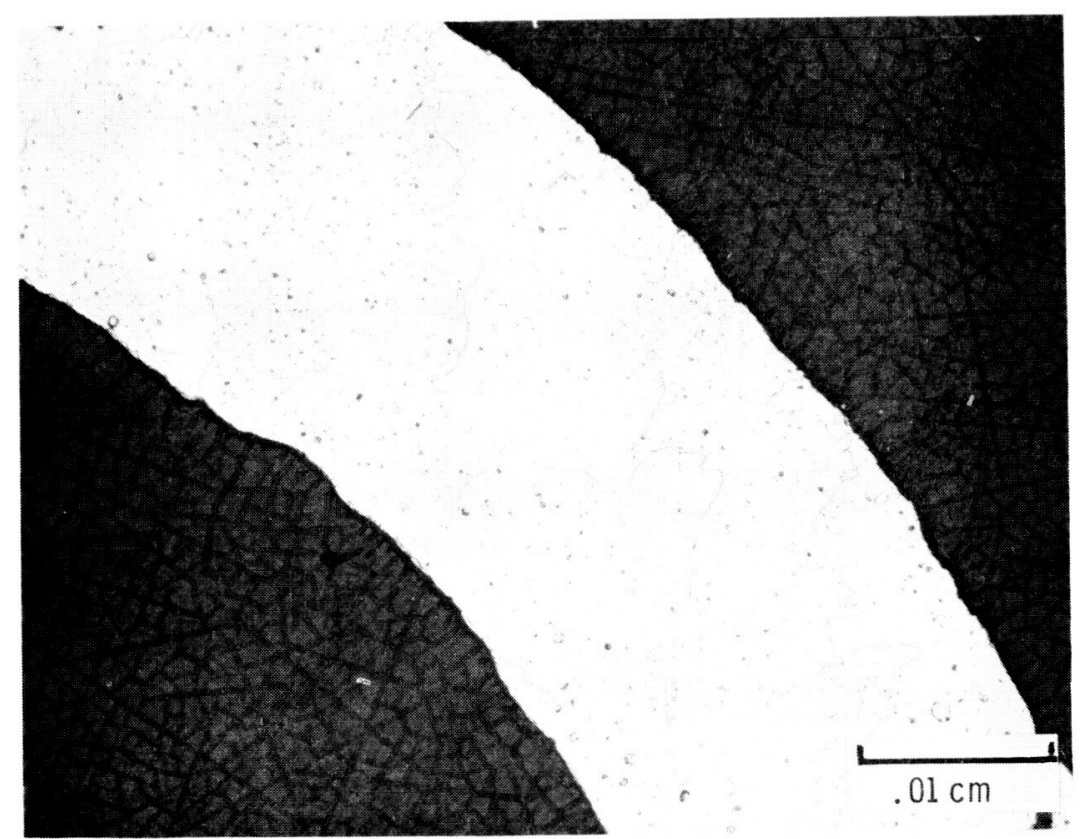

After

FIGURE 6. - CROSS SECTION OF PT/Y ${ }_{2} \mathrm{O}_{3}$ TUBE BEFORE AND AFTER TESTING FOR 2000 HR AT $1300{ }^{\circ} \mathrm{C}$ IN CO 2. 


\section{ORCINAL PAGE IS OF POOR OUALITY}

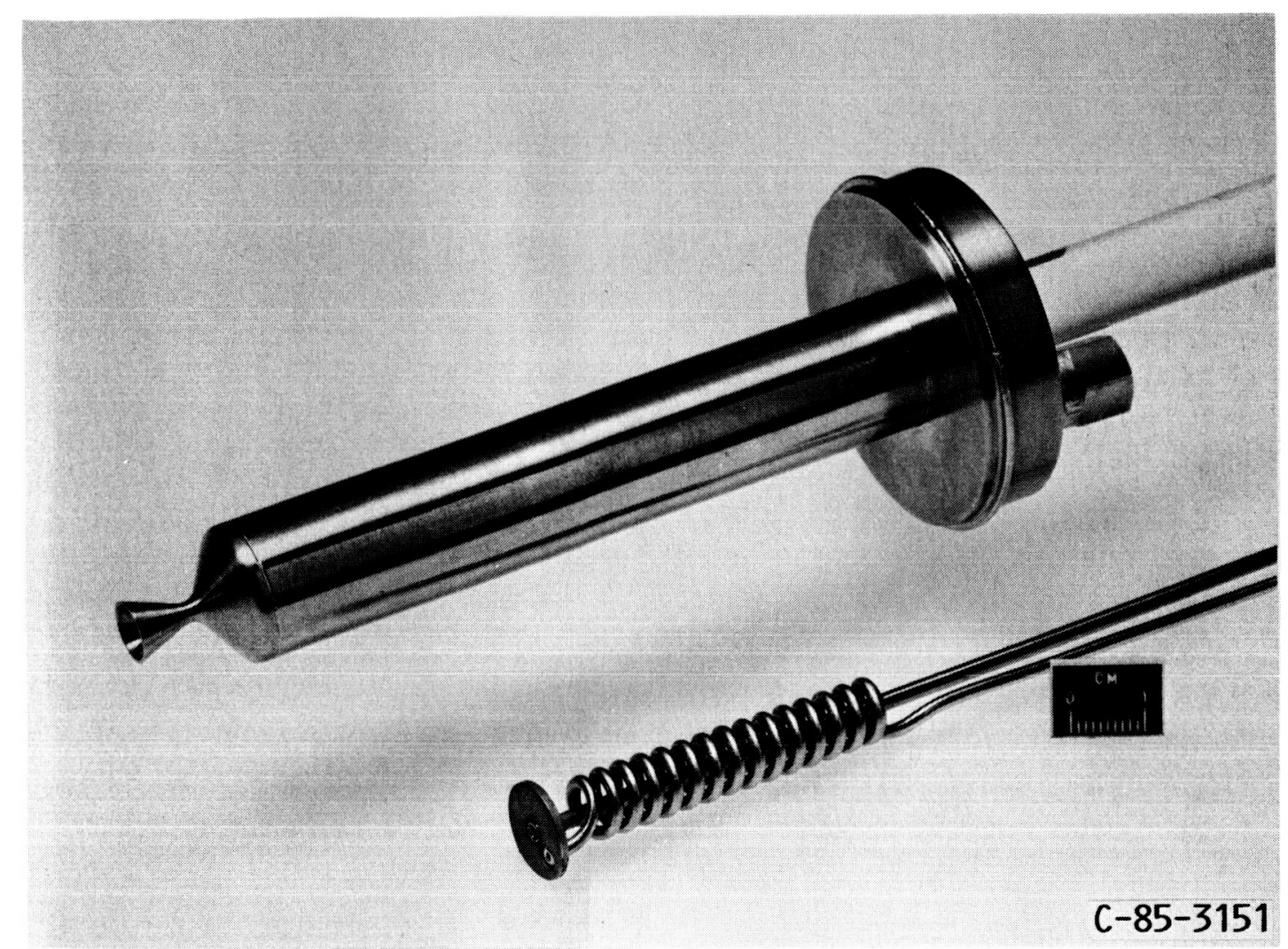

FIGURE 7. - LABORATORY MODEL OF RESISTOJET AND COILED TUBE HEATER.

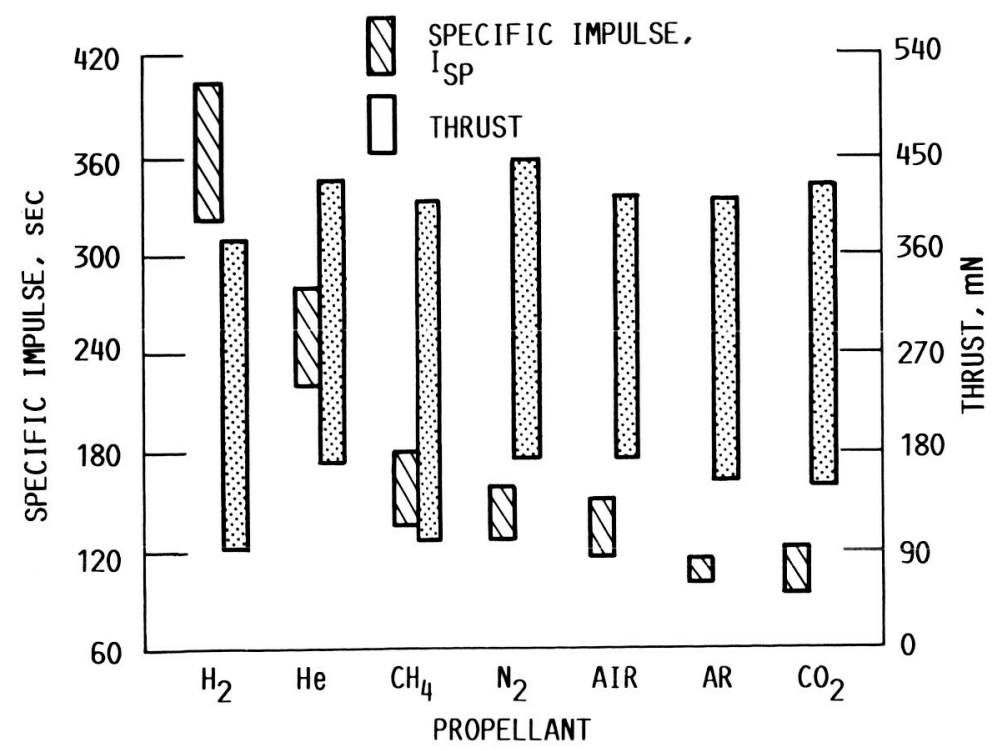

FIGURE 8. - SPECIFIC IMPULSE AND THRUST RANGES FOR A MULTIPROPELLANT RESISTOJET OPERATED ON VARIOUS PROPELLANTS AT A HEATER TEMPERATURE OF $1400{ }^{\circ} \mathrm{C}$. 


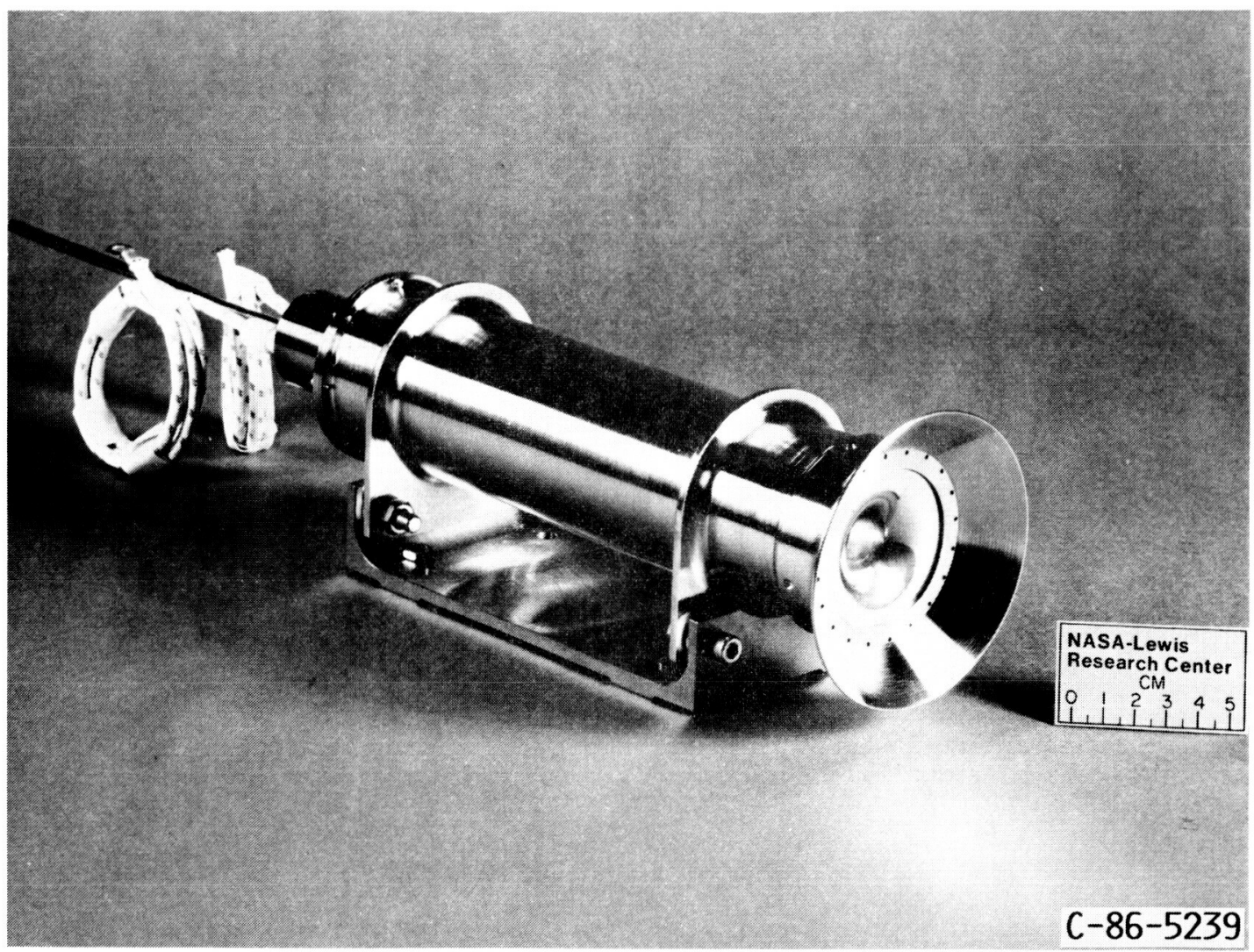

FIGURE 9. - ENGINEERING MODEL OF RESISTOJET.

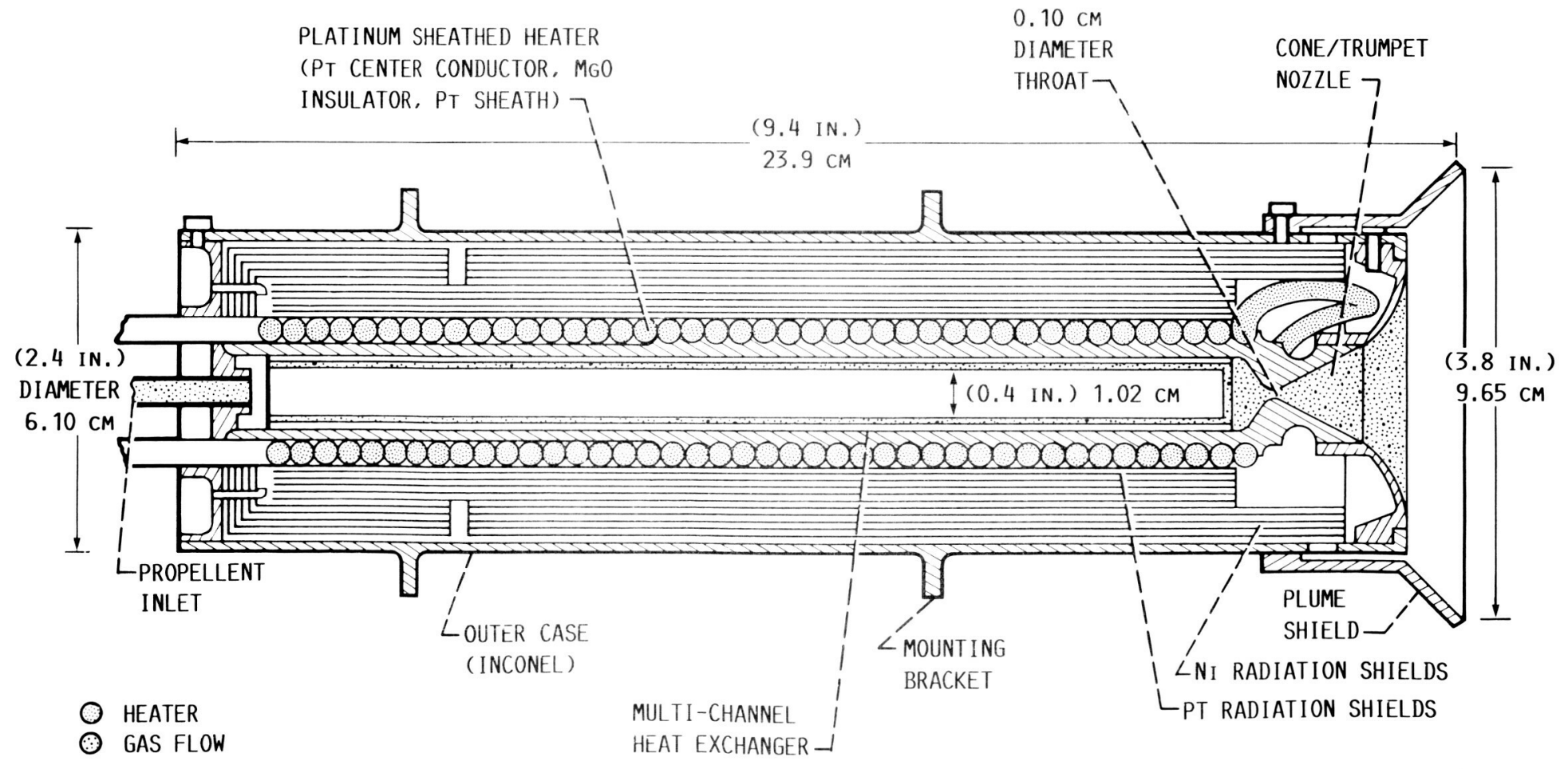

FIGURE 10. - ADVANCED DEVELOPMENT ENGINEERING MODEL RESISTOJET. 


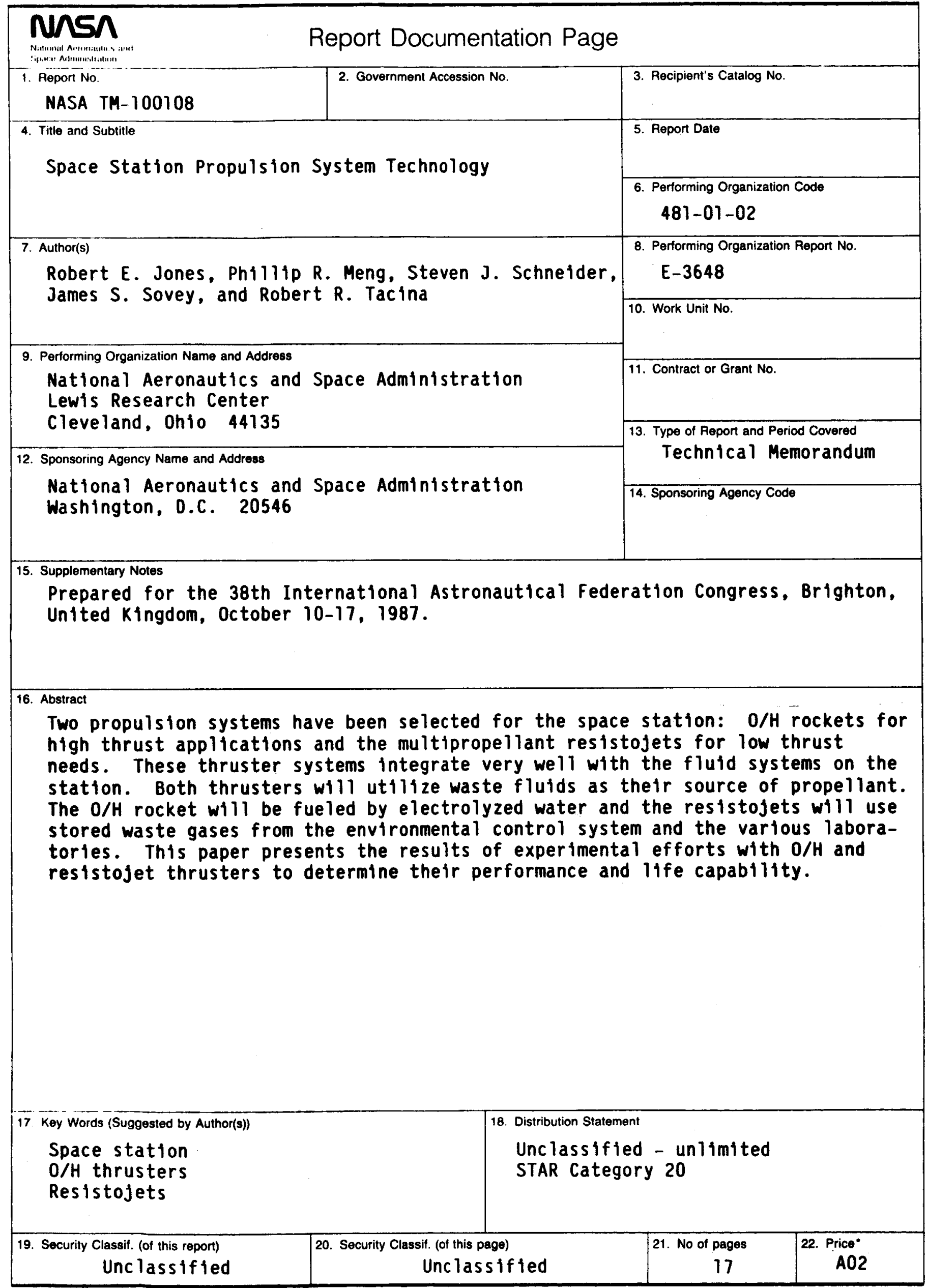

